\title{
WORKPLACE MONITORING FOR EXPOSURES TO RADON AND TO OTHER NATURAL SOURCES IN EUROPE: INTEGRATION OF MONITORING FOR INTERNAL AND EXTERNAL EXPOSURES
}

\author{
M. A. Lopez ${ }^{1, *}$, L. Currivan ${ }^{2}$, R. Falk ${ }^{3}$, P. $\mathrm{Olko}^{4}$, C. Wernli ${ }^{5}$ and C. M. Castellani ${ }^{6}$ \\ ${ }^{1}$ CIEMAT-Internal Dosimetry; Avda. Complutense 22, 28040 Madrid, Spain \\ ${ }^{2}$ RPII, 3 Clonskeagh Square, Clonskeagh Road, Dublin 14, Ireland \\ ${ }^{3}$ SSI, SE-17116 Stockholm, Sweden \\ ${ }^{4}$ Institute of Nuclear Physics, Radzikowskiego 152, PL 31442 Krakow, Poland \\ ${ }^{5}$ PSI, 5232 Villigen, Switzerland \\ ${ }^{6}$ ENEA-IRP, Via dei Colli 16, 40136 Bologna, Italy
}

\begin{abstract}
Part of the action of the EURADOS working group (European Radiation Dosimetry Group) on 'Harmonisation of Individual Monitoring in Europe' was to investigate how the results from personal dosemeters for external radiation, from monitoring for internal exposure and from workplace monitoring, can be combined into a complete and consistent system of individual monitoring. To facilitate this work, the 'EURADOS questionnaire Q3' relating to radon and other natural sources of radiation in the workplace was distributed to relevant institutes across Europe. A total of 24 countries replied to the questionnaire. This study offers an important overview on actual regulations, national standards and reference levels for protection of employees from radon and other natural sources in different workplace scenarios. Information was also collected on individual monitoring and area monitoring to determine individual doses in workplaces with elevated levels of natural radiation. The article discusses in detail the results obtained showing by country the reference level in workplaces for radon gas and other natural sources. In both instances, exposures in mines, other underground workplaces, industry workplaces/ waterworks, offices, schools and day-care homes were considered. The resultant data clearly indicate that there is a need for harmonisation among countries, not least in the areas of regulation and use of reference levels in the workplace.
\end{abstract}

\section{INTRODUCTION}

The aim of the EURADOS (European Radiation Dosimetry Group) working group on 'Harmonisation of Individual Monitoring' is to promote harmonisation in the field of individual monitoring of occupational exposures in the European countries.

The task of the work package 'Integration of monitoring for internal and external exposure' is to investigate how the results from personal dosemeters for external radiation, from workplace monitoring and from monitoring for internal exposure, can be combined into a complete and consistent system of individual monitoring.

The European Commission Basic Safety Standard (BSS) Directive is revised in line with scientific developments approximately every $10-15$ years. The most recent revision, which is based on the general recommendations of the International Commission on Radiological Protection (ICRP) Publication $60^{(1)}$, is the European Directive 96/29/ EURATOM ${ }^{(2)}$. This revision differs from earlier versions in that provisions are laid down concerning exposure to natural sources of ionising radiation. It is also important to take note of the IAEA and the International Labour

*Corresponding author: ma.lopez@ciemat.es
Office, which jointly prepared the Safety Report on radiation protection in workplaces other than mines $^{(3)}$.

Exposure to radon and radon decay products at home and in the workplace are considered one of the greatest risks from ionisation radiation. The connection between radon and lung cancer has been already established through epidemiological studies carried out in many countries ${ }^{(4)}$. High concentrations of radon in air have been found in mines as well as in other workplaces, such as waterworks, caves and closed-out mines open to visitors, underground stores and shopping centres, spas, kindergartens, schools, factories, shops, public buildings and offices.

In addition, other naturally occurring radioactive material (NORM) can cause significant increases in exposure. NORM can be defined as all naturally occurring radioactive materials where human activities have increased the potential for exposure in comparison to the unaltered situation. Examples of such activities are the phosphate industry, processing of metal ores, zircon sands and refractory materials, manufacture of rare earth, manufacture and use of thorium compounds, the titanium dioxide pigment industry and oil and gas extraction. Estimation of doses received from NORM in the workplace is difficult to access, as the pathways by which workers can receive a significant exposure are not well known. 


\section{A. LOPEZ ET AL}

In order to study the current situation regarding the implementation of Title VII of the European Directive 96/29/EURATOM a Eurados questionnaire entitled 'Eurados 2002 Questionnaire 3 Exposures to radon and to other natural radiation at workplace in European countries' was distributed to 28 countries. Replies have been received from 24 countries. This study offers an important overview on actual regulations, national standards and reference levels for protection of employees from radon and other natural sources in different workplace scenarios (e.g. underground areas, industry, waterworks, offices, schools, homes). Information was also collected on individual monitoring and area monitoring to determine individual doses in workplaces with elevated levels of natural radiation.

Results are presented by country showing the reference level for workplaces in $\mathrm{Bq} \mathrm{m}^{-3}$ or $\mathrm{Bqhm}{ }^{-3} \mathrm{y}^{-1}$ for radon gas and the reference level for workplaces in $\mathrm{mSv}$ or $\mathrm{mSv}^{-1}$ for natural sources. In both instances, consideration is given to exposures in mines, other underground workplaces, industry workplaces/waterworks, offices, schools and day-care homes.

The investigation of the data clearly indicates that a need for harmonisation exists among European countries in the areas of regulation and use of reference levels in the workplace. Some countries in Europe prefer very detailed and strict regulations; others prefer to restrict the regulations to more qualitative statements at the level of principles, objectives or commitment to best effort.

\section{RECOMMENDATIONS CONCERNING PROTECTION OF WORKERS AND MEMBERS OF THE PUBLIC FROM EXPOSURE TO RADON AND OTHER NATURAL RADIATION DERIVING FROM WORK ACTIVITIES}

In this section an overview is given of the most important recommendations regarding exposure to radon and other natural radiation sources from the ICRP to the requirements in the European Commission BSS Directive. Also to be taken into account are other recommendations and regulations such as the International Safety Standards published by the International Atomic Energy Agency (IAEA).

The European Union prepared and adopted the Council Directive 96/29/Euratom ${ }^{(2)}$ following the publication by the ICRP of Publication 60: '1990 Recommendations of the International Commission on Radiological Protection, ${ }^{\text {(1) }}$ and the IAEA of the 'International Basic Safety Standards for Protection against Ionising Radiation and the Safety of Radiation Sources, ${ }^{(5)}$. The BSS deals with protection against ionising radiation from artificial and natural radiation sources and contains demands for limits for workers and members of the general public. The BSS is also concerned with work activities involving the presence of natural radiation sources that may lead to a significant increase in exposure to workers or members of the public and which cannot be disregarded, from a radiation protection perspective. The BBS does not deal with exposure to radon in dwellings.

Title VII of Council Directive 96/29/EURATOM includes special provisions concerning exposure to natural sources of ionising radiation, by recognising the specific problems that need addressing when the source of exposure has not been artificially generated but is of natural origin. Member States shall identify work activities that may be of concern (Article 40). Where a Member State has deemed a type of work activity to be of concern, appropriate monitoring of exposure shall be put in place and as necessary corrective measures to reduce exposure shall be implemented (Article 41).

Because exposures of this nature had not been specifically dealt with before, the EU Commission directed a Group of European Experts on Radiation Protection, established under the terms of Article 31 of the EURATOM Treaty, to provide guidance on the implementation of Title VII of the BSS. Detailed guidance and recommendations on the identification of work activities and related workplaces and on the nature of appropriate have been published ${ }^{(6,7)}$. In general, these recommendations follow the guidelines set up by the $\operatorname{ICRP}^{(1)}$.

A suggestion of ranges of Action Levels is given in these documents both for radon in workplaces and for effective dose where work activities include NORM, Table 1. For a working environment the suggested Action Level of time averaged radon activity concentration is in the range $500-1000 \mathrm{~Bq} \mathrm{~m}^{-3(7)}$. Using the dose-conversion convention approach of ICRP $65^{(8)}$ and an occupancy factor of $2000 \mathrm{~h} \mathrm{y}^{-1}$, it should correspond to a dose of $3-6 \mathrm{mSv} \mathrm{y}^{-1}$.

Besides these recommendations and regulations note should also be taken of a study that has been undertaken for the Directorate General for Environment of the European Commission, in order to provide information for the Article 31 experts and EU Member States, on effluent and dose control from European Union NORM Industries ${ }^{(9)}$. The following tasks were undertaken leading to an extensive report:

Task 1. Identification of industries giving rise to NORM discharges. Review of the quantities of NORM wastes discharged into the sea and into the rivers or disposed of in the EU.

Task 2. Review of the regime of prior authorisation and discharge authorisation in Member States (how it is implemented legally and in practice). 
WORKPLACE MONITORING FOR EXPOSURES TO NATURAL SOURCES

Table 1. Suggested action levels for work activities with NORM.

\begin{tabular}{|c|c|c|c|c|c|}
\hline \multicolumn{3}{|c|}{ Scenario } & \multicolumn{3}{|c|}{ Effective dose $\mathrm{mSv}^{-1}$} \\
\hline & $<1$ & $1-6$ & $6-20$ & $>20$ & $20-50$ \\
\hline Normal & $\begin{array}{l}\text { No regulation } \\
\text { necessary }\end{array}$ & $\begin{array}{l}\text { Lower level of } \\
\text { regulation }\end{array}$ & $\begin{array}{l}\text { Higher level of } \\
\text { regulation }\end{array}$ & $\begin{array}{l}\text { Process not } \\
\text { permitted }^{*}\end{array}$ & \\
\hline Unlikely & $\begin{array}{l}\text { No regulation } \\
\text { necessary }\end{array}$ & & $\begin{array}{l}\text { Lower level of } \\
\text { regulation }\end{array}$ & $\begin{array}{l}\text { Higher level of } \\
\text { regulation }\end{array}$ & $\begin{array}{l}\text { Process not } \\
\text { permitted }^{*}\end{array}$ \\
\hline
\end{tabular}

*Through review of the working practices, it is necessary to make a detailed assessment of doses. If these prove to exceed the worker dose limit as set out in the Directive 96/29/EURATOM, then the process must cease.

Task 3. Review of dose constraints and compliance with dose limits (as they relate to discharges from NORM industries).

Task 4. Provision of guidance for a realistic assessment methodology for the assessment of doses as a result of public exposure from the activities of NORM industries.

Task 5. Development of criteria for the quick identification of effluent discharges potentially requiring regulatory control.

\section{TERMINOLOGY}

\section{Units for measurement of radon and radon progeny concentration in air}

The dose and the harm from radon in air is due to inhalation of the radon progeny, which deposit in the airways and the lungs. The dose is dependent on many factors, e.g. aerosol concentration, aerosol size distribution, the amount of 'un-attached fraction', breathing rate, etc. Historically the concentration of the radon progeny concentration were measured and used in mines as an estimate of the dose. The radon progeny concentration is expressed as potential alpha energy concentration (PAEC), in $\left(\mathrm{J} \mathrm{m}^{-3}\right)$, $\left(\mathrm{Bq} \mathrm{m}^{-3}, \mathrm{EEC}\right)$ or Working Level (WL) $)^{(10)}$.

The 'equilibrium factor' $(\mathrm{F})$ is the relation between radon gas concentration and the PAEC $\left(\mathrm{Bq} \mathrm{m}^{-3}\right.$, EEC). This factor, normally assumed to be 0.4 , depends on environmental factors, such as aerosol concentration and ventilation rate.

Conversion of units (concentration):

$$
\begin{aligned}
& 1 \mathrm{~Bq} \mathrm{~m}^{-3}\left({ }^{222} \mathrm{Rn}\right)=F^{-1} \mathrm{~Bq} \mathrm{~m}^{-3}(\mathrm{EEC}) \\
& =F^{-1} \times 5.56 \times 10^{-6} \mathrm{~mJ} \mathrm{~m}^{-3}=F^{-1} \times 0.27 \mathrm{mWL}
\end{aligned}
$$

\section{Units for exposure from radon and radon progeny in air}

The 'activity exposure' of an individual to ${ }^{222} \mathrm{Rn}$ is the time integral over the activity concentration of
${ }^{222} \mathrm{Rn}$ or PAEC to which the individual is exposed during a definitive period of time. Its unit is e.g. $\mathrm{Bq} \mathrm{h} \mathrm{m}{ }^{-3}\left({ }^{222} \mathrm{Rn}\right.$-gas) or $\mathrm{J} \mathrm{h} \mathrm{m}^{-3}$ (PAEC).

The 'potential alpha-energy exposure' of miners is often expressed in the unit WLM (working level month); 1 WLM corresponds to an exposure of 1 WL during the reference working period of 1 month $(\approx 170 \mathrm{~h})$.

Conversion of units (exposure) :

$$
1 \mathrm{WLM}=F \times 6.3 \times 10^{5} \mathrm{~Bq} \mathrm{~h} \mathrm{~m}^{-3}\left({ }^{222} \mathrm{Rn} \text {-gas }\right)
$$

\section{Dose from exposure to radon and radon progeny}

The dose from exposure to radon and radon progeny is dependent on many factors, e.g. aerosol concentration, aerosol size distribution, un-attached fraction etc. ${ }^{(11,12)}$. The ICRP $66^{(13)}$ human respiratory tract model, which is used for calculation of other inhaled radionuclides gives an excess risk factor for lung cancer that is 2-3 times the factor derived from miner radon epidemiology. The value recommended by ICRP is based on results from radon epidemiological studies in mines, and the excess lung cancer risk is converted to dose.

8-nSv per Bq $\mathrm{h} \mathrm{m}^{-3}$ (EEC) or $5 \mathrm{mSv}$ per WLM (dose-conversion convention approach) ${ }^{(8)}$

9-nSv per $\mathrm{Bq} \mathrm{h} \mathrm{m}{ }^{-3}$ (EEC) (dose-conversion convention approach) ${ }^{(14)}$

24-nSv per $\mathrm{Bq} \mathrm{h} \mathrm{m}{ }^{-3}$ (EEC) or $15 \mathrm{mSv} / \mathrm{WLM}$ (dosimetric approach) $^{(15)}$

Assuming $2000 \mathrm{~h}$ working period over a year and an equilibrium factor of 0.4 , a mean radon gas concentration of $500 \mathrm{~Bq} \mathrm{~m}^{-3}$ correspond to a dose of $3.2 \mathrm{mSv} \mathrm{y}^{-1(8)}, 3.6 \mathrm{mSv} \mathrm{y}^{-1(14)}$ and $9.6 \mathrm{mSv} \mathrm{y}^{-1}$ (dosimetric approach). 
EURADOS QUESTIONNAIRE Q3-EXPOSURE TO RADON AND TO OTHER SOURCES OF NATURAL RADIATION AT WORKPLACES IN EUROPEAN COUNTRIES

In order to study the current situation in relation to the implementation of the European Directive 96/ 29/EURATOM and in particular Title VII concerning the exposure to radon and other sources of natural radiation in the workplaces a questionnaire was sent to 28 European countries. The questionnaire contained two parts: the first enquiring about exposure to radon in workplaces and the second regarding exposure to all other natural radiation in workplaces. The questionnaire was distributed via E-mail by June 2002. A year later 24 countries had replied as shown in Table 2.

The questionnaire responses have been summarised in Tables 2 to 5 and further presented in Figures 1 to 10.

Information collated in the course of the study is summarised below with replies to each question dealt with individually.

Table 2. The 24 countries that responded to the questionnaire.

\begin{tabular}{|c|c|c|c|}
\hline $\begin{array}{l}\text { Country } \\
\text { code }\end{array}$ & Country & $\begin{array}{l}\text { Country } \\
\text { code }\end{array}$ & Country \\
\hline $\mathrm{BE}$ & Belgium & $\mathrm{LT}$ & Lithuania \\
\hline BG & Bulgaria & NL & Netherlands \\
\hline $\mathrm{CZ}$ & Czech Republic & NO & Norway \\
\hline $\mathrm{DK}$ & Denmark & PL & Poland \\
\hline $\mathrm{EE}$ & Estonia & PT & Portugal \\
\hline FI & Finland & $\mathrm{CS}$ & $\begin{array}{l}\text { Serbia and } \\
\text { Montenegro }\end{array}$ \\
\hline $\mathrm{DE}$ & Germany & SK & Slovak Republic \\
\hline GR & Greece & SI & Slovenia \\
\hline HU & Hungary & ES & Spain \\
\hline IR & Ireland & SE & Sweden \\
\hline IT & Italy & $\mathrm{CH}$ & Switzerland \\
\hline LV & Latvia & UA & Ukraine \\
\hline
\end{tabular}

Table 3. Examples of radon reference level used in mines.

\begin{tabular}{ll}
\hline Ireland & $400 \mathrm{~Bq} \mathrm{~m}^{-3}$ \\
Belgium & $800 \mathrm{~Bq} \mathrm{~m}^{-3}$ \\
Hungary & $1000 \mathrm{~Bq} \mathrm{~m}^{-3}$ \\
Switzerland & $3000 \mathrm{~Bq} \mathrm{~m}^{-3}$ \\
Germany & $2 \mathrm{MBq} \mathrm{h}^{-3} \mathrm{y}^{-1}$ \\
Sweden & $2.5 \mathrm{MBq} \mathrm{h} \mathrm{m}^{-3} \mathrm{y}^{-1}$ \\
Bulgaria & $4 \mathrm{WLM} \mathrm{y}^{-1}$ or \\
& $\mathrm{PAEC}=5 \times 10^{4} \mathrm{MeV} \mathrm{L}^{-1}$ \\
Poland & $0.8 \mu \mathrm{J} \mathrm{m}^{-3}$ \\
Italy & $3 \mathrm{mSv} \mathrm{y}^{-1}$ \\
\hline
\end{tabular}

\section{Exposure to radon at workplaces}

National standards/reference levels for protection of employees from exposure to radon in all workplaces

Of the countries that replied, a total of 18 countries have national standards/reference levels (Ireland, Belgium, Greece, Sweden, Bulgaria, Slovak Republic, Denmark, Italy, Hungary, Czech Republic, Poland, Lithuania, Finland, Ukraine, Norway, Germany, Switzerland, Latvia and Serbia and Montenegro), 2 countries are going to implement them (Estonia and Slovenia) while 3 countries are without them (Netherlands, Portugal and Spain).

\section{Reference level used for workplace}

Four different workplaces were selected, mines, other underground workplaces, industry workplaces/waterworks, and offices, schools, and daycare homes. The most commonly used unit is $\mathrm{Bq} \mathrm{m}^{-3}$ (air concentration) or Bq h m${ }^{-3} \mathrm{y}^{-1}$ (yearly exposure) to radon gas, Tables 3 to 5 . A few countries use PAEC, $\mu \mathrm{J} \mathrm{m}^{-3}$ or WLM $\mathrm{y}^{-1}$ in defining the reference level. Italy has set the reference level unit to dose $\left(\mathrm{mSv}^{-1}\right)$ for work in mines. In order to compare the reference levels from the different countries a conversion to radon gas concentration is carried out. The PAEC is converted to radon gas concentration using the assumption that the equilibrium factor $(F)$ is 0.4 . The exposure (e.g. $\mathrm{MBq} \mathrm{h} \mathrm{m} \mathrm{m}^{-3} \mathrm{y}^{-1}$ ) is converter to radon gas concentration $\left(\mathrm{Bq} \mathrm{m} \mathrm{m}^{-3}\right.$ ) assuming 170 working hours per month. The dose is converted to radon gas concentration using the relation: $5 \mathrm{mSv}$ per $\mathrm{WLM}^{(8)}$. Examples of units and reference levels used in different countries are given in the Table 3.

Figures 1-4 show the reported reference levels for radon in different workplaces. It can be seen that the reference level in offices, schools and day-care homes are lower than for the other work places and tend to be in line with acceptable levels for members of the public.

Individual monitoring in workplaces with elevated levels of radon. A total of 11 countries carry out individual monitoring (Poland, Greece, Slovak Republic, Sweden, Ireland, Czech Republic, Finland, Slovenia, Ukraine, Germany and Latvia), while 2 countries (Hungary and Serbia and Montenegro) are going to and 11 others do not.

Workplaces/area monitoring to determine individual doses in workplaces with elevated levels of radon. A total of 13 countries (Italy, Belgium, Poland, Slovak Republic, Sweden, Czech Republic, Greece, Slovenia, Norway, Germany, Switzerland, Estonia and Hungary) determine individual doses, while 3 countries (Ireland, Finland and Serbia \& Montenegro) are going to and 8 countries do not. 
WORKPLACE MONITORING FOR EXPOSURES TO NATURAL SOURCES

Table 4. Reference level used for workplaces-normalised to $\mathrm{Bq} \mathbf{~ m}^{-3}$-enforced for radon gas.

\begin{tabular}{|c|c|c|c|c|}
\hline \multirow[t]{2}{*}{ Country } & \multicolumn{4}{|c|}{ Reference level used for workplaces } \\
\hline & Mines & $\begin{array}{c}\text { Other } \\
\text { underground } \\
\text { workplaces }\end{array}$ & $\begin{array}{c}\text { Industry } \\
\text { workplaces/ } \\
\text { waterworks }\end{array}$ & $\begin{array}{l}\text { Offices, schools, } \\
\text { day-care homes }\end{array}$ \\
\hline Belgium & 400 & 400 & 400 & 400 \\
\hline Bulgaria & 3600 & 3600 & 3600 & \\
\hline Czech Rep. & 1000 & 1000 & 1000 & 400 \\
\hline Denmark & - & 400 & 400 & 400 \\
\hline Estonia & - & & 1100 & \\
\hline Finland & 400 & 400 & 400 & 400 \\
\hline Germany & 1000 & 1000 & 1000 & 200 \\
\hline Greece & 400 & 400 & 400 & 400 \\
\hline Hungary & 1000 & 1000 & 1000 & \\
\hline Ireland & 400 & 400 & 400 & 400 \\
\hline Italy & 500 & 500 & 500 & 500 \\
\hline Latvia & - & 400 & 1000 & 200 \\
\hline Lithuania & 1000 & 1000 & 400 & 400 \\
\hline Norway & 1000 & 100 & 200 & 200 \\
\hline Poland & 360 & 360 & 160 & 160 \\
\hline Serbia \& Montenegro & 1000 & 1000 & 1000 & 400 \\
\hline Slovak Republic & 1000 & 1000 & 1000 & 500 \\
\hline Slovenia & 1000 & 1000 & 1000 & 600 \\
\hline Sweden & 1250 & 400 & 400 & 400 \\
\hline Switzerland & 3000 & 3000 & 3000 & 1000 \\
\hline Ukraine & 750 & 750 & 750 & 200 \\
\hline
\end{tabular}

Table 5. Reference level used for workplaces- $m S v, m S v y^{-1}$-Enforced for natural sources.

\begin{tabular}{|c|c|c|c|c|}
\hline \multirow[t]{2}{*}{ Country } & \multicolumn{4}{|c|}{ Reference level used for workplaces } \\
\hline & Mines & $\begin{array}{c}\text { Other } \\
\text { underground } \\
\text { workplaces }\end{array}$ & $\begin{array}{c}\text { Industry } \\
\text { workplace/ } \\
\text { waterworks }\end{array}$ & $\begin{array}{l}\text { Offices, schools, } \\
\text { day-care homes }\end{array}$ \\
\hline Belgium & 1 & 1 & 1 & 1 \\
\hline Czech Rep. & 6 & 6 & 6 & 20 \\
\hline Denmark & & & 5 & \\
\hline Estonia & & & 20 & \\
\hline Finland & 1 & 1 & 1 & 1 \\
\hline Germany & & & 6 & \\
\hline Greece & 1 & 1 & 1 & 1 \\
\hline Hungary & 20 & 20 & 20 & \\
\hline Ireland & 1 & 1 & 1 & 1 \\
\hline Italy & 1 & & 1 & \\
\hline Latvia & & 1 & 1 & \\
\hline Lithuania & 50 & 50 & 50 & 5 \\
\hline Netherlands & 1 & 1 & 1 & 1 \\
\hline Norway & 20 & 20 & 20 & 20 \\
\hline Poland & 1 & 1 & 1 & 1 \\
\hline Portugal & 50 & 20 & & \\
\hline Slovenia & 50 & 50 & 1 & 1 \\
\hline
\end{tabular}

\section{Measurement methods}

There are many techniques available for the measurement of radon and radon progeny. Depending on the situation, short or long measurement periods can be chosen along with choosing between measurement of radon gas or radon progeny. Active devices, where the airborne radon progeny are collected on an air filter, are used to assess the concentration of 


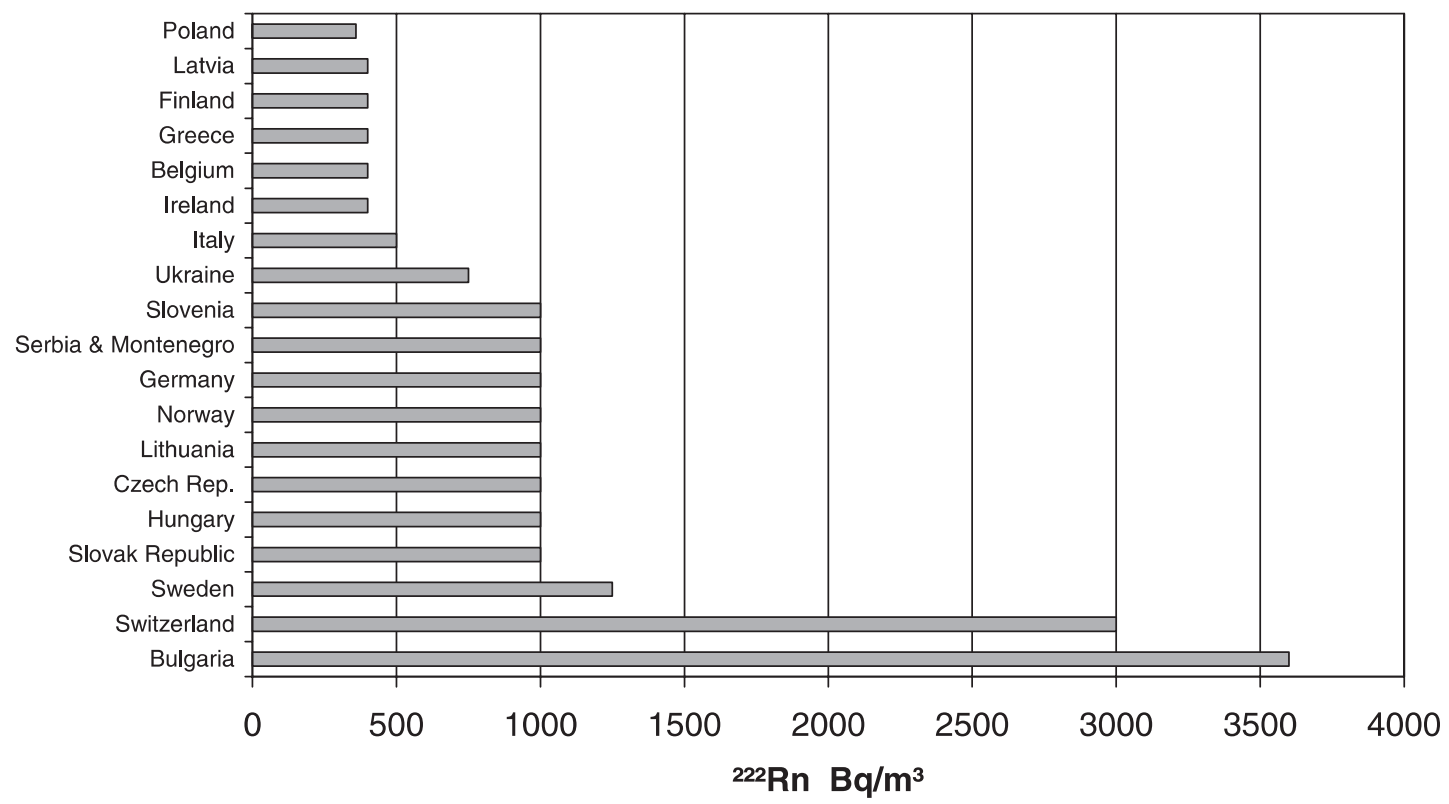

Figure 1. Reference level in mines $\left(\mathrm{Bq} \mathrm{m}^{-3},{ }^{222} \mathrm{Rn}\right)$.

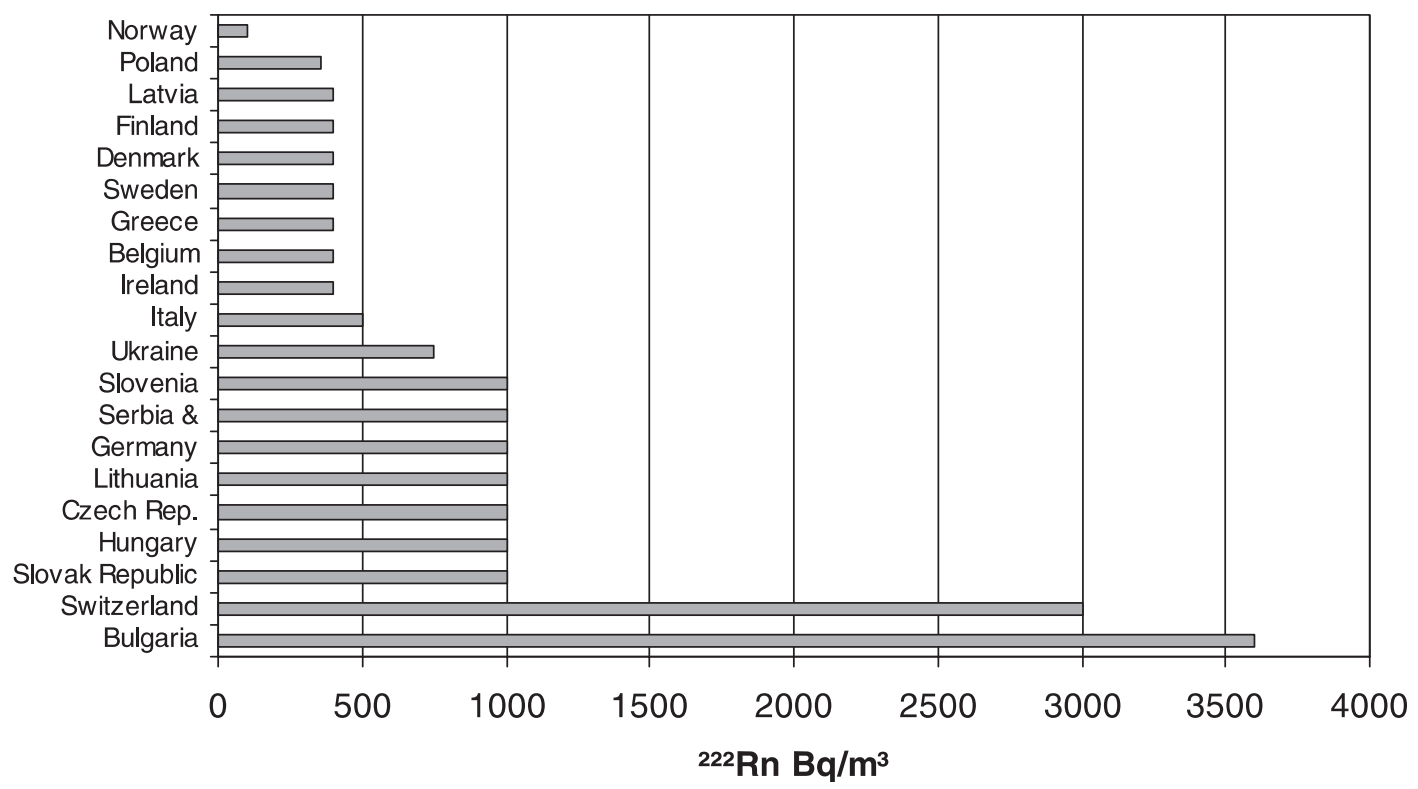

Figure 2. Reference level for other underground workplaces ( $\left.\mathrm{Bq} \mathrm{m}{ }^{-3},{ }^{222} \mathrm{Rn}\right)$.

radon progeny ${ }^{(16)}$. Passive devices, such as alphatrack detectors and 'electret' ion chambers are the most widely used type of radon detectors for long-term measurements. Alpha-track detectors use a solid-state nuclear-track detector (SSNTD) that is sensitive to alpha radiation ${ }^{(17)}$. More detailed information of the different techniques used can be found in the literature ${ }^{(3,18,19)}$.

Individual dose record for those employees monitored in workplaces with elevated levels of radon. A total of 9 countries (Ireland, Finland, Poland, Czech Republic, 
WORKPLACE MONITORING FOR EXPOSURES TO NATURAL SOURCES

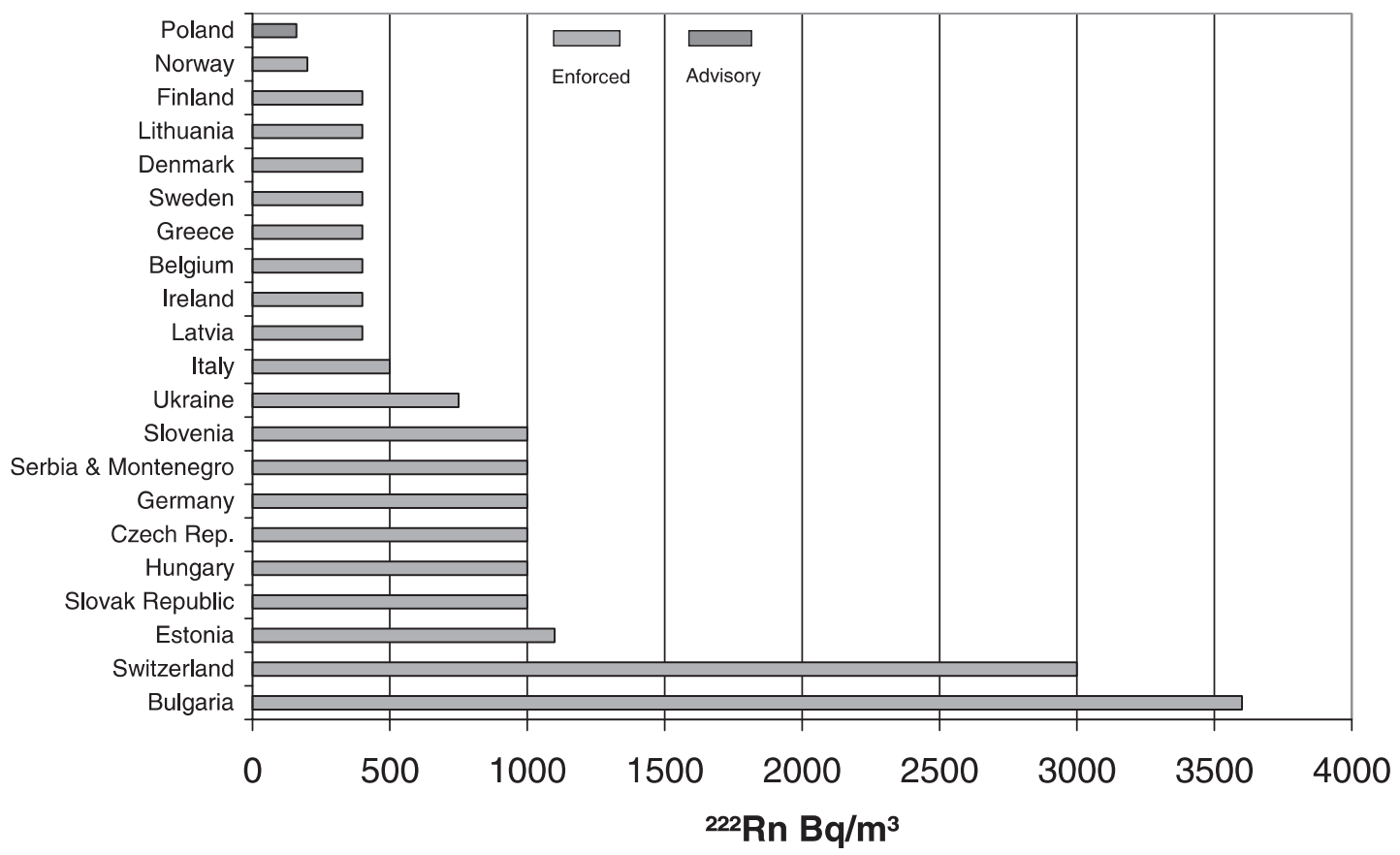

Figure 3. Reference level for industry workplaces/waterworks ( $\left.\mathrm{Bq} \mathrm{m} \mathrm{m}^{-3},{ }^{222} \mathrm{Rn}\right)$.

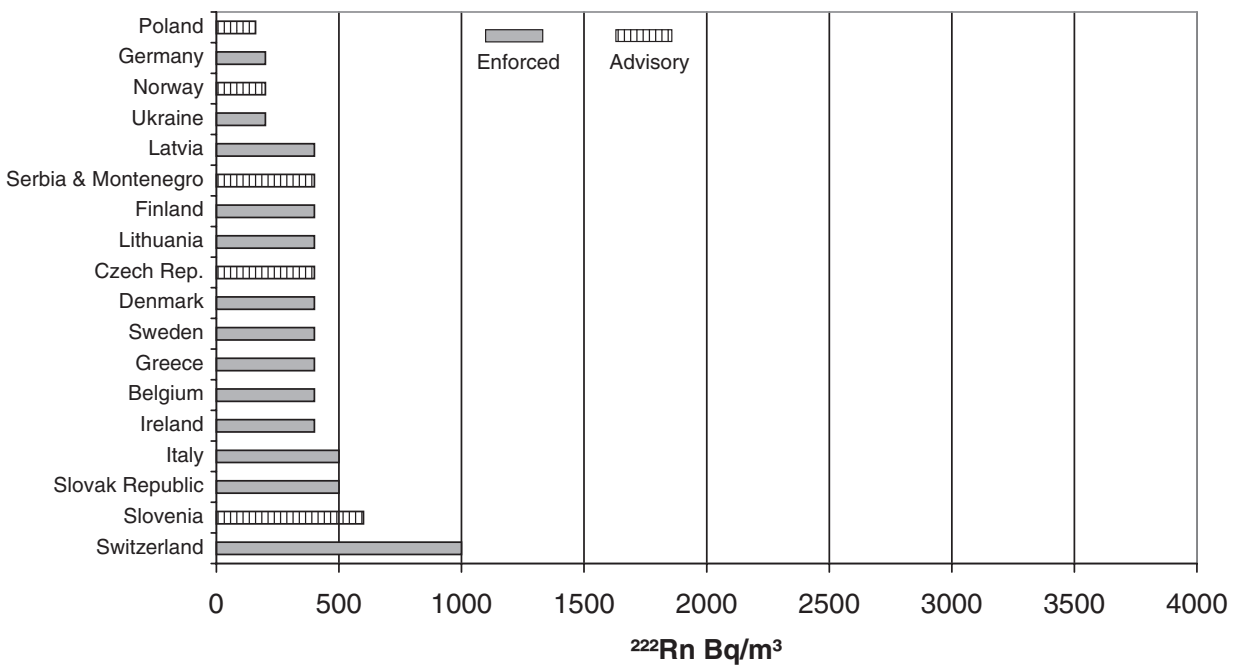

Figure 4. Reference level for offices, schools and day-care homes ( $\left.\mathrm{Bq} \mathrm{m}{ }^{-3},{ }^{222} \mathrm{Rn}\right)$.

Slovak Republic, Slovenia, Ukraine, Germany and Estonia) have individual dose record while 4 countries (Ireland, Finland, Ukraine and Serbia and Montenegro) are going to and 7 countries do not.

Minimum dose record level reported for radon exposure at workplaces with elevated levels of radon. To compare the different minimum dose record levels reported a conversion of exposure in $\mathrm{Bq} \mathrm{h} \mathrm{m} \mathrm{h}^{-3} \mathrm{y}^{-1}$ to $\mathrm{mSv}^{-1}$ is carried out using dose-conversion convention approach $^{(8)}$. The large range of values given by the respondents may be due to different interpretation of the concept of minimum dose record. 


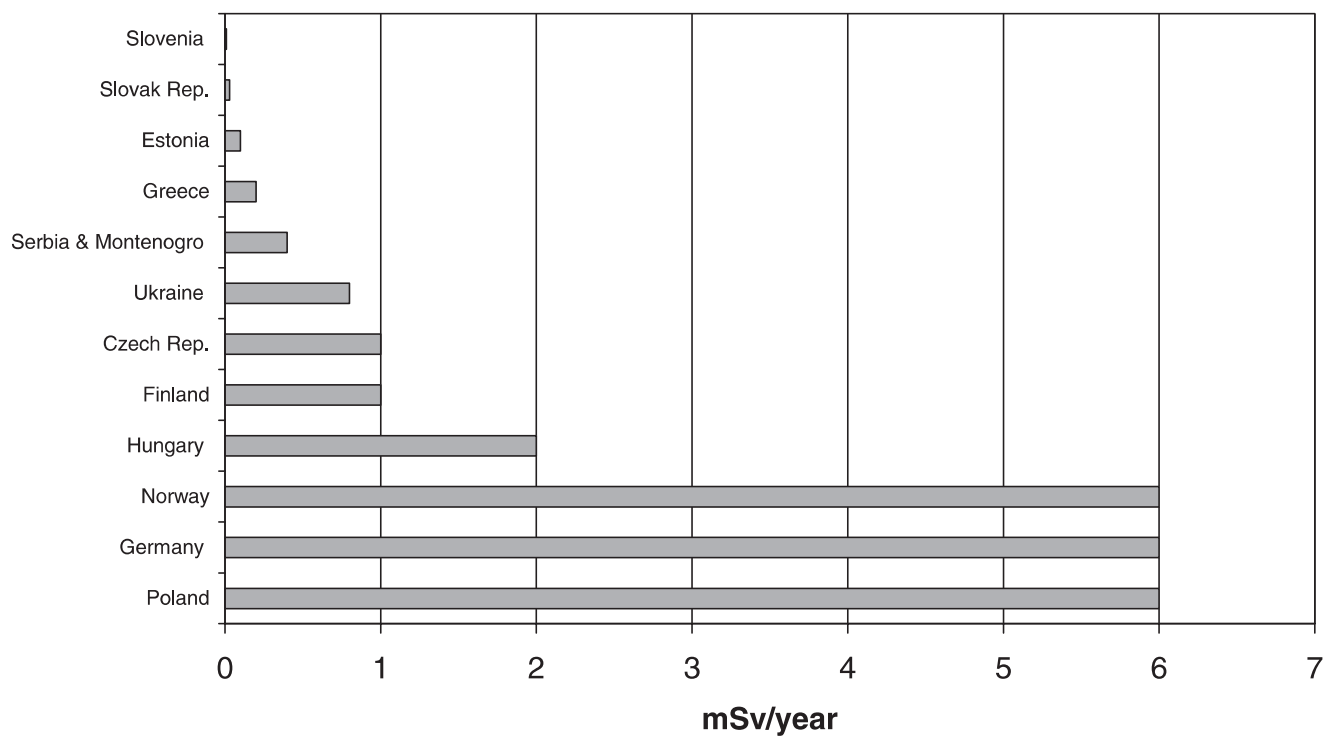

Figure 5. Minimum dose record level $\left(\mathrm{mSv} \mathrm{y}^{-1}\right)$ reported for radon at workplaces.

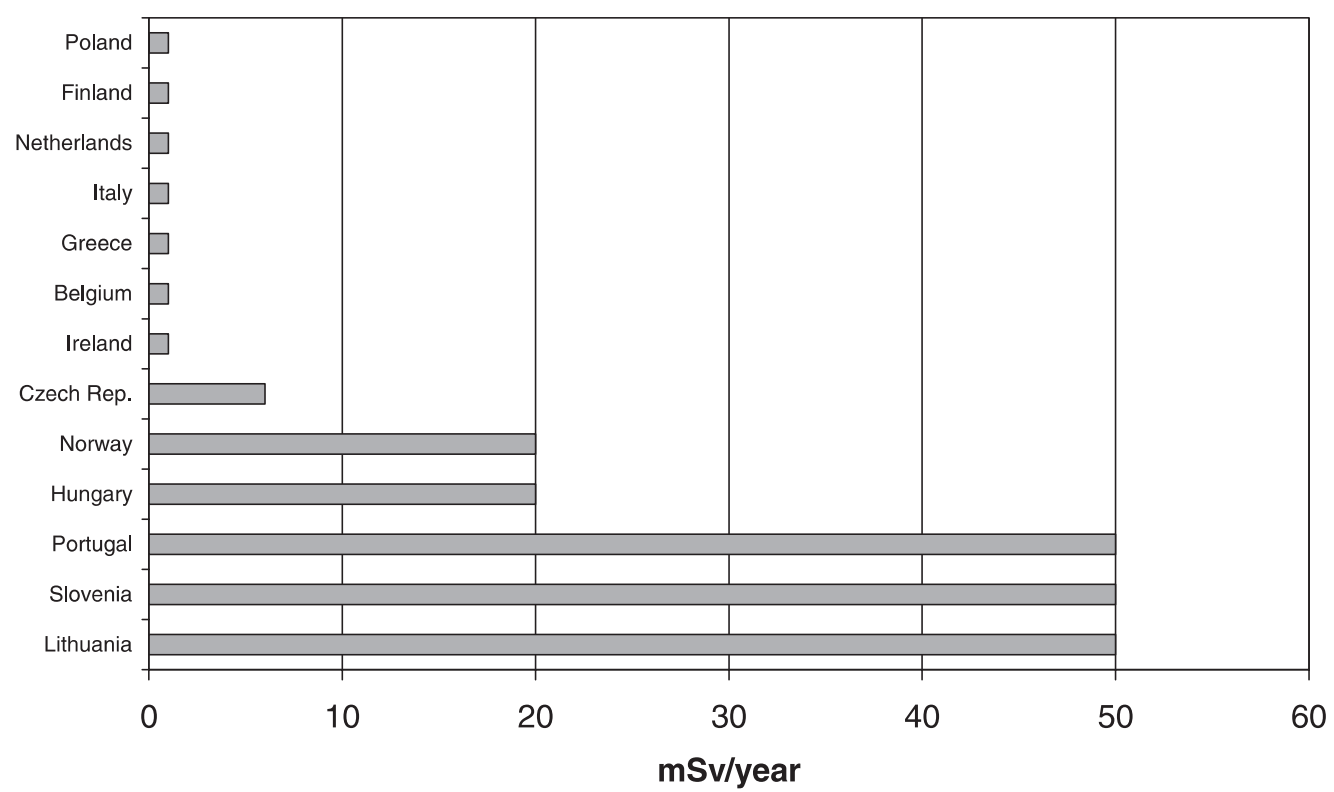

Figure 6. Enforced reference level in mines for natural sources.

\section{Exposure to other natural radiation sources in workplaces}

National standards/reference levels for protection of employees from other natural radiation sources in all workplaces

A total of 15 countries have national standards/ reference levels (Ireland, Belgium, Greece, Denmark, Italy, Hungary, Czech Republic, Netherlands, Poland,
Lithuania, Finland, Slovenia, Norway and Germany), 3 countries are going to (Estonia and Sweden) while 3 countries are without (Netherlands, Portugal and Spain).

\section{Reference level used for workplace}

Four different workplaces were selected: mines, other underground workplaces, industry 


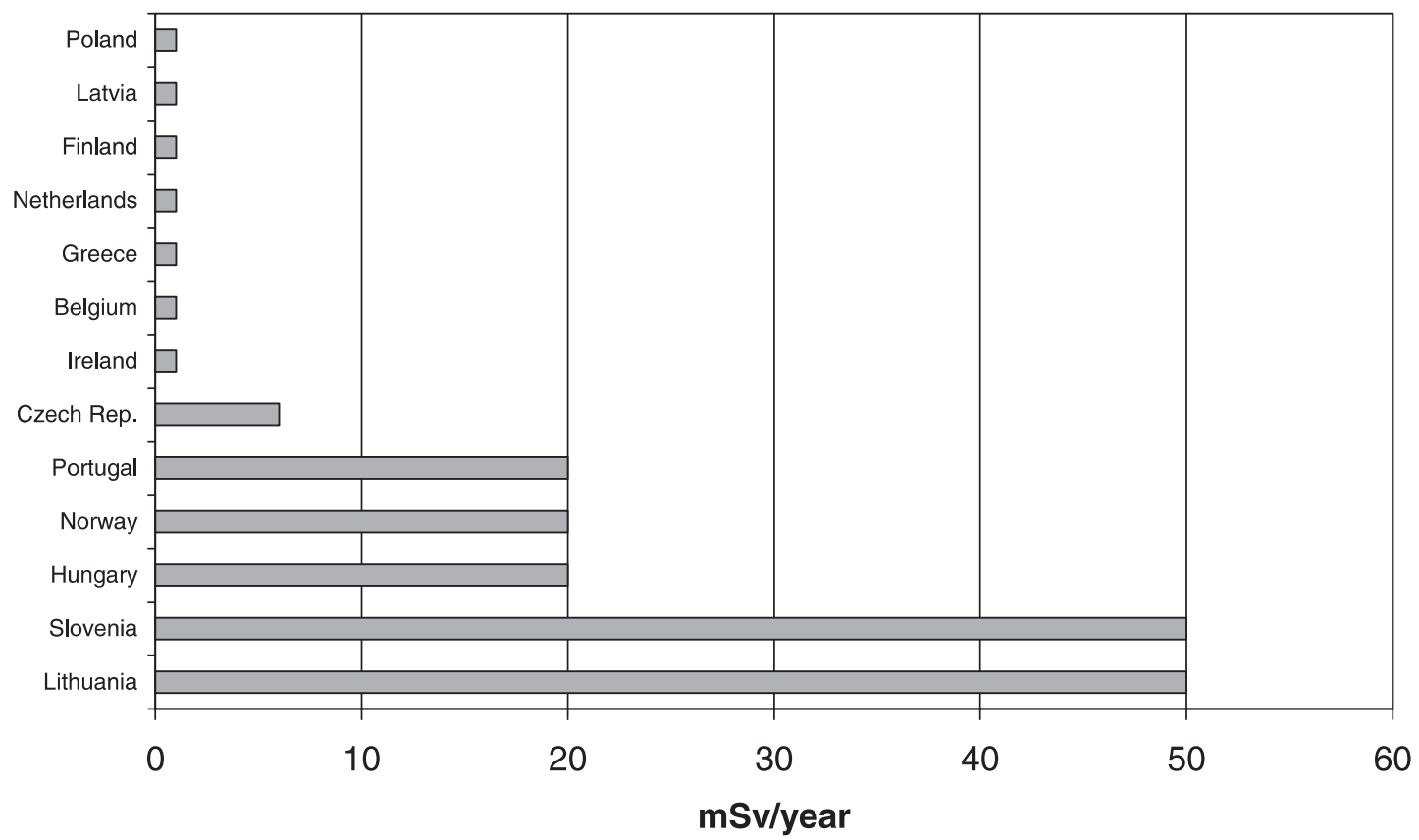

Figure 7. Enforced reference level in other underground workplaces for natural sources.

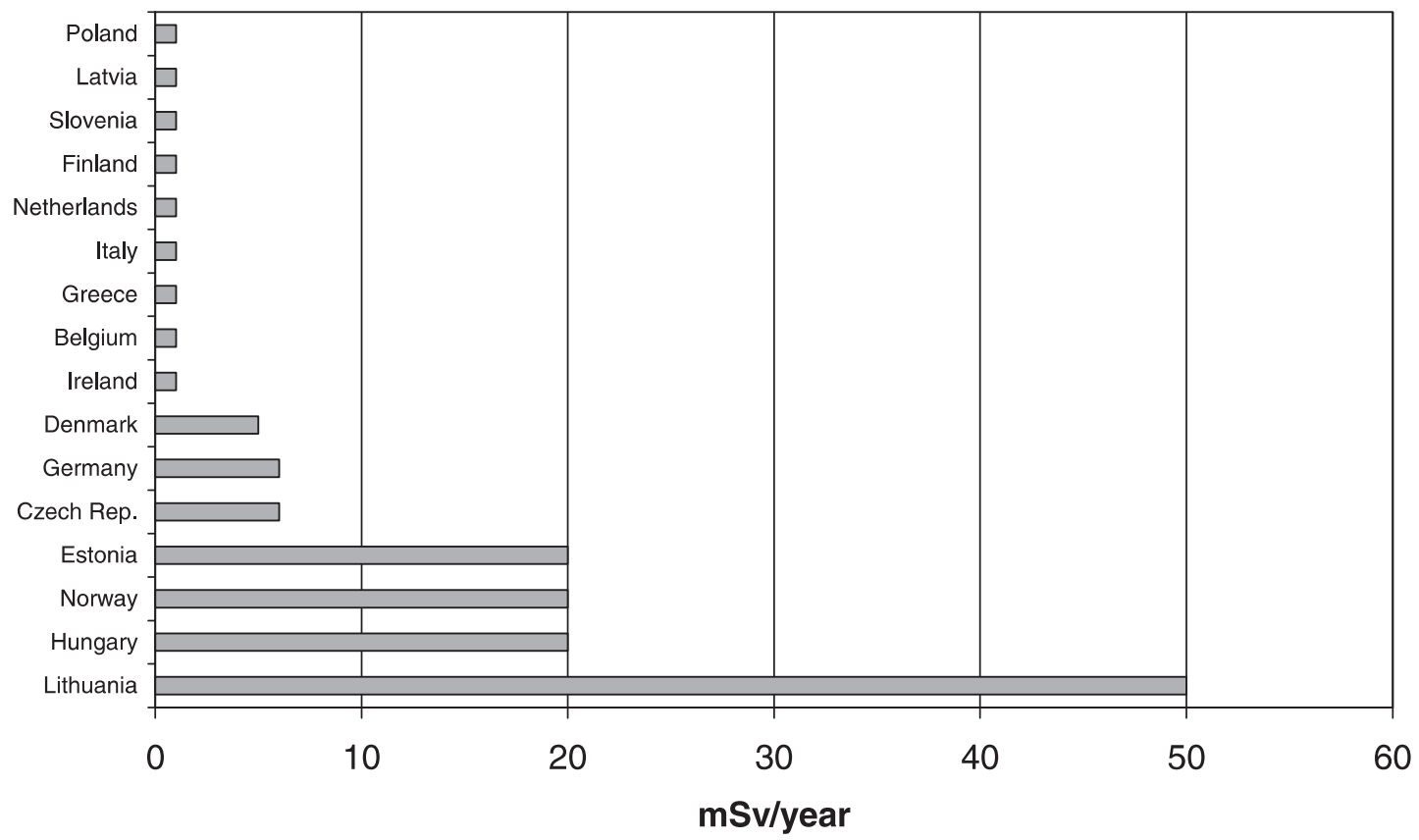

Figure 8. Enforced reference level in industry workplaces/waterworks for natural sources.

workplaces/waterworks and offices, schools, and day-care homes. In general the unit quoted for the reference level is $\mathrm{mSv}^{-1}$. There is a range of values quoted among respondents as shown in Figures 6-9.
Individual monitoring in workplaces with elevated levels of natural radiation. A total of 12 countries carry out individual monitoring (Finland, Greece, Lithuania, Poland, Netherlands, Czech Republic, 


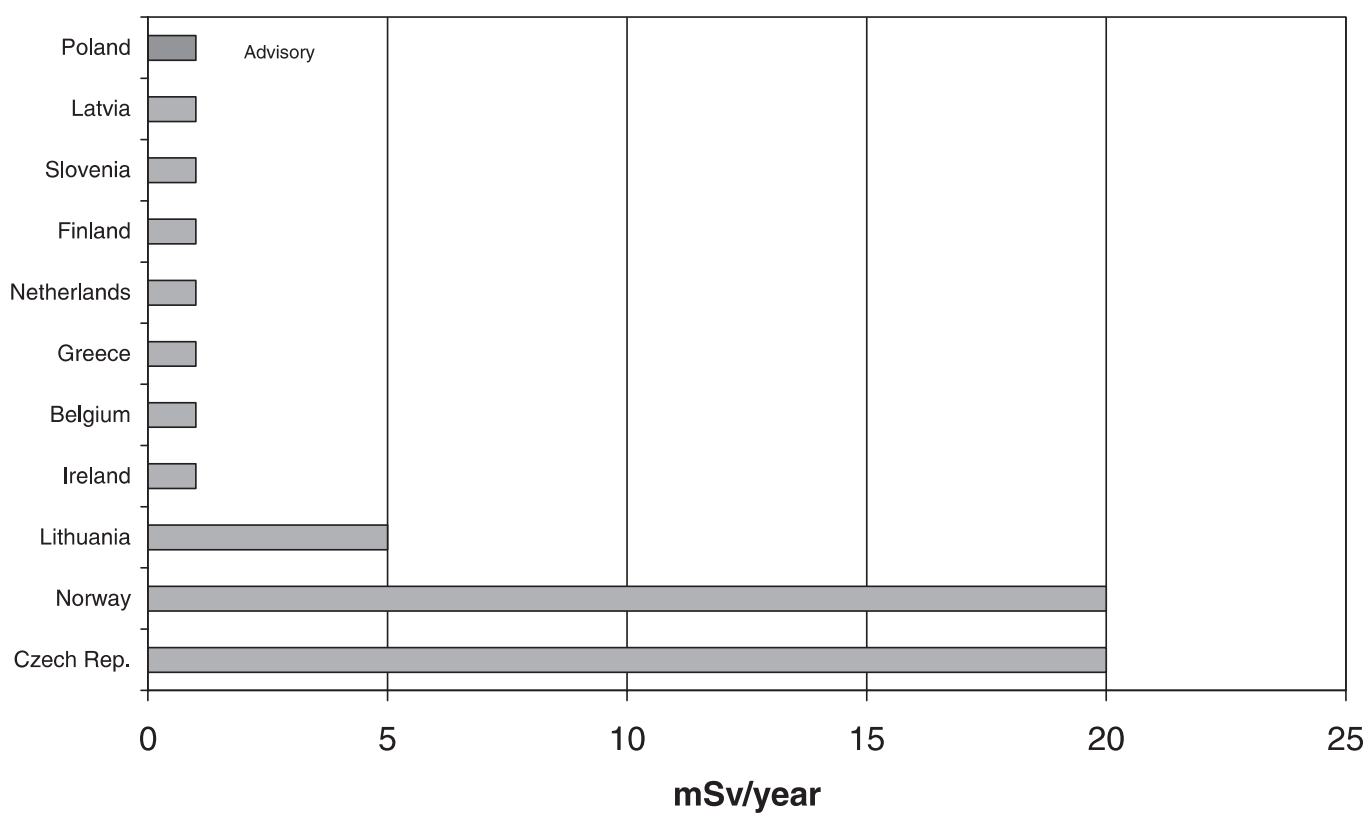

Figure 9. Enforced reference level in offices, schools and day-care homes for natural sources.

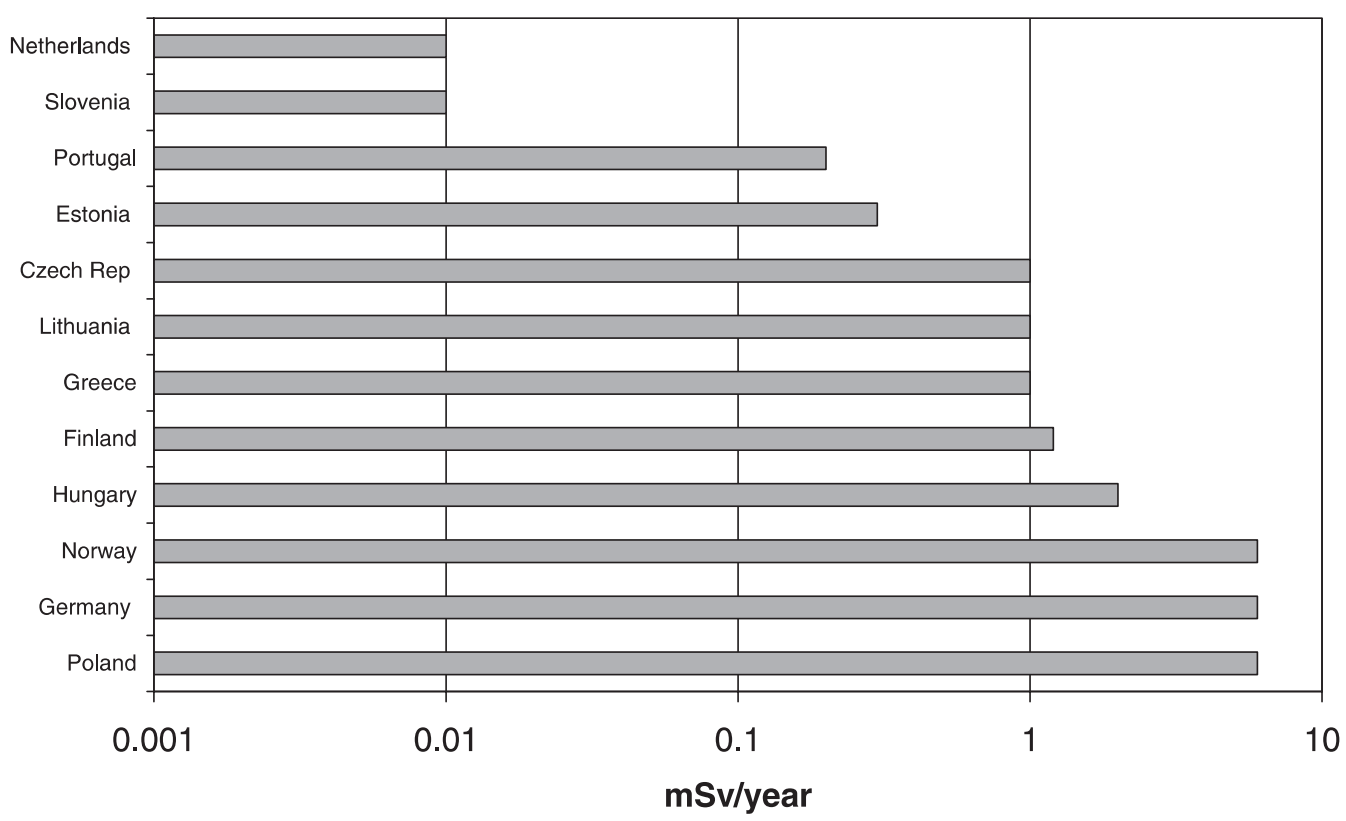

Figure 10. Minimum dose record level for workplaces with elevated levels of natural radiation.

Portugal, Italy, Slovenia, Germany, Ireland and Belgium), 5 countries do not and the remainder might if high levels are found.

Workplacelarea monitoring to determine individual doses in workplaces with elevated levels of natural radiation. Fifteen countries carry out workplace/area monitoring, three countries do not. The other countries stated that it might be undertaken if high levels are found.

Individual dose records held for those employees monitored in workplaces with elevated levels of natural radiation. Thirteen countries have individual dose 
record, two countries do not. A number of countries stated that it would be undertaken if high levels of radiation were found.

Minimum dose record level reported for other natural sources of exposure at workplaces. Figure 10 shows the minimum dose record level for workplaces with elevated levels of natural radiation. Again a large range of values was given by the respondents and may be due to different interpretation of the concept of minimum dose record.

\section{SUMMARY BY COUNTRY}

Participants were encouraged to add additional information about the techniques and methodologies used in their country, e.g. type of dosemeter, to make evaluations of radon and other sources of natural radiation. Below is a summary of the information received by the participating countries.

\section{Belgium}

\section{Radon}

Belgium has in place a national standard/reference level for radon in the workplace. The level implemented in workplaces is $800 \mathrm{~Bq} \mathrm{~m}^{-3}$. Individual monitoring of workers does not take place in workplaces with elevated radon levels. However, in this circumstance workplace/area monitoring is undertaken to determine individual doses. As yet the matter of recording and maintaining individual dose records and the minimum dose record level have not been defined.

\section{Other sources of natural radiation}

Belgium has in place national standards/reference levels for other natural sources of radiation in the workplace. The levels implemented for each type of workplace is $1 \mathrm{mSv} \mathrm{y}^{-1}$. Individual monitoring of workers and workplace/area monitoring takes place in workplaces with elevated levels of natural radiation. The recording and maintaining of individual dose records and a minimum dose record level have yet to be defined.

\section{Bulgaria}

Bulgaria has a national reference level based on exposure to radon progeny. This is set at 4 WLM $\mathrm{y}^{-1}$ or PAEC $=5 \times 10^{4} \mathrm{MeV} \mathrm{L}^{-1}$ for underground workplaces, industry and waterworks. The integrated ${ }^{222} \mathrm{Rn}$ gas measurements are based on diffusion chambers with alpha-track detectors (Kodak-Pathe LR-115/II). This technique is traceable to a primary standard. The measurements of ${ }^{222} \mathrm{Rn}$ progeny are based on grab-sampling methods.
No individual monitoring or workplace/area monitoring takes place in workplaces with elevated radon levels. Subsequently, no individual dose records or minimum dose record levels exist.

\section{Czech Republic}

\section{Radon}

In the Czech Republic the Atomic Act No.13/2002 Sb. was transposed into law on 1 July 2002. Czech Republic has in place national standards/reference levels for radon in the workplace. The enforced reference level implemented for mines, underground workplaces and industry/waterworks is $1000 \mathrm{~Bq} \mathrm{~m}^{-3}$. In addition, an advisory reference level for uranium mines is set at $1260 \mathrm{~Bq} \mathrm{~m}^{-3}$ and $400 \mathrm{~Bq} \mathrm{~m}^{-3}$ for other mines. An advisory level of $400 \mathrm{~Bq} \mathrm{~m}^{-3}$ is in place for offices, schools and day-care homes. Individual monitoring and workplace/area monitoring takes place in workplaces with elevated radon levels. Individual dose records are maintained with a minimum dose record level of $1 \mathrm{mSv} \mathrm{y}^{-1}$ being recorded.

\section{Other sources of natural radiation}

Czech Republic has in place national standards/ reference levels for other natural sources of radiation in the workplace. The enforced level for underground workplaces, industry and waterworks is $6 \mathrm{mSv} \mathrm{y}^{-1}$. The enforced level for offices, schools and day-care homes is $10 \mu \mathrm{Gy} \mathrm{h} \mathrm{h}^{-1}$. There is an advisory reference level for underground workplaces (other than mines), industry and waterworks of $1 \mathrm{mSv}$. There is an advisory level for offices, schools and day-care homes of $1 \mu \mathrm{Gy} \mathrm{h} \mathrm{h}^{-1}$. Individual monitoring of workers and workplace/area monitoring takes place in workplaces with elevated levels of natural radiation. The minimum dose record level is set at $1 \mathrm{mSv} \mathrm{y}^{-1}$ for workplaces other than offices etc., which has yet to be determined.

Exposure to radon and NORM for employees is carried out by 2 laboratories, National Radiation Protection Institute, Praha and National Nuclear, Chemical and Biological Institute, Pribram. Additional information can be found at http://www. suro.cz/en/index.html.

\section{Denmark}

\section{Radon}

Denmark has in place a national standard/reference level for workplaces and it is set at $400 \mathrm{~Bq} \mathrm{~m}^{-3}$. As no mines exist in Denmark reference levels are not necessary. No individual or workplace monitoring takes place in workplaces with elevated radon levels. 


\section{Other sources of natural radiation}

Denmark has in place a national standard/reference level for other natural sources of radiation in the workplace. The levels implemented for industry and waterworks is $0.0025 \mathrm{mSv} \mathrm{h}^{-1}$. No individual monitoring of workers takes place in workplaces with elevated levels of natural radiation. However, workplace/area monitoring takes place in some selected industries.

Also worth noting is that the Radiation Protection Authorities in Denmark, Finland, Iceland, Norway and Sweden have issued recommendation for Naturally Occurring Radioactivity in the Nordic Countries. Information is to be found at http://www.ssi.se/ english/Flaggboken.pdf.

\section{Estonia}

\section{Radon}

As yet, in Estonia, there are no national standards/ reference levels for workplaces with elevated radon levels. Exposure to radon in the workplace is assessed for radiation workers in Sillamae, where work on remediation of a tailings pond is taking place. For this purpose, a classification system for radon exhalation rate and radon concentration in terms of target values, limit values and trigger values is in place. Internal doses are calculated on the basis of radon measurement data on the tailings pond. As yet, measurements in offices, schools, day-care homes and mines are not carried out. A minimum dose record level of $0.1 \mathrm{mSv} \mathrm{y}^{-1}$ is implemented. Radon measurement techniques include the 'ALPHAGUARD PQ2000/MC50' for measurement of radon concentration and radon monitors, RM-3 and Gamma Data.

\section{Other sources of natural radiation}

As yet, in Estonia, there are no national standards/ reference levels for workplaces with elevated levels of other natural radiation. However, a dose limit of $20 \mathrm{mSv} \mathrm{y}^{-1}$ exists for radiation workers in two industries, one processing NORM materials and the other remediating a tailings pond. A radon reference level of $1100 \mathrm{~Bq} \mathrm{~m}^{-3}$ exists for the tailings pond.

The Estonian Radiation Protection Centre (ERPC) is obliged by law to carry out radiation monitoring and assess radiation levels, including natural sources, in the workplace.

\section{Finland}

\section{Radon}

Finland has in place a national standard/reference level for workplaces with elevated radon levels. The enforced level for each type of workplace is $400 \mathrm{~Bq} \mathrm{~m}^{-3}$. Individual monitoring of workers does not take place in workplaces with elevated radon levels. Individual dose records are maintained with the minimum dose record level set at $1 \mathrm{mSv} \mathrm{y}^{-1}$.

A set of action levels exist and are defined as annual average concentration during working hours. Where action levels are exceeded the employer must take action to reduce the concentration. If this is unsuccessful the workers are classified as exposed workers, by taking into account the technical and economic situation. The workers are monitored accordingly with dose limits of $20 \mathrm{mSv} \mathrm{y}^{-1}$ and $3000 \mathrm{~Bq} \mathrm{~m}^{-3}$ being applied.

The basic method for determining radon concentration in above ground workplaces is a 2-month $\alpha$-track measurement during winter. In underground mines and excavation works grab samples-Lucas Cell - are used to determine average concentrations. Methods and devices used for assessing the individual doses shall be approved for this purpose by the Regulatory Authority (STUK). Approved alphatrack measurements are provided by ASTK and one private company. Continuous recording devices for performing radon measurements are also provided by several institutes and private companies.

\section{Other sources of natural radiation}

In Finland national standards/reference levels exist for other sources of natural radiation. For mines a reference level of $1 \mathrm{mSv} \mathrm{y}^{-1}$ is in place. Workplace/ area monitoring takes place if gamma doses are expected to exceed $1 \mathrm{mSv} \mathrm{y}^{-1}$ and if expected to exceed $6 \mathrm{mSv} \mathrm{y}^{-1}$ individual monitoring takes place. Individual dose records will be maintained in a national dose register. The minimum dose record level is set at $0.1 \mathrm{mSv}$ per month for individual monitoring while no minimum is set for workplace monitoring: all dose assessments are recorded.

Gamma monitoring is undertaken with personal dosemeters or by using survey meters. Inhalation rate are assessed by collecting gross air samples on glass fibre filters that are then analysed using gamma spectrometry. The above methods are subject to approval by STUK. Personal dosemeters must be provided by an approved dosimetry service. STUK carries out inhalation dose measurements in conjunction with inspection of workplaces.

The Radiation Protection Authorities in Denmark, Finland, Iceland, Norway and Sweden have issued recommendation for Naturally Occurring Radioactivity in the Nordic Countries. Information is to be found at http://www.ssi.se/english/Flaggboken.pdf.

\section{Germany \\ Radon}

Germany has in place national standards/reference levels for workplaces with elevated radon levels. The enforced level for mines, exhibition caves radon spas 
and water supply stations is $2 \mathrm{MBq} \mathrm{h} \mathrm{m} \mathrm{m}^{-3} \mathrm{y}^{-1}$. An advisory level of $200 \mathrm{~Bq} \mathrm{~m}^{-3}$ exists for offices, schools and day-care homes.

Individual and workplace/area monitoring takes place in some workplaces. Individual dose records are maintained with the minimum dose record level being set at $6 \mathrm{mSv}$. Monitoring is with passive and active radon measurement systems. Measurement systems and services are subject to system of quality control by the Federal Office for Radiation Protection. This includes quality assurance and proficiency testing.

\section{Other sources of natural radiation}

In the case of other sources of natural radiation national standards/reference levels exist only for specific workplaces using uranium, thorium and their daughters which are not used for nuclear applications. The enforced level is set at $6 \mathrm{mSv}^{-1}$. Individual and workplace monitoring takes place in these industries. Individual dose records are maintained with a minimum dose record level being set at $6 \mathrm{mSv} \mathrm{y}^{-1}$.

Monitoring methods include dust sampling, body counting, excretory analysis and gamma dosimetry. As before, measurement systems and services are subject to a system of quality control by the Federal Office for Radiation.

\section{Greece}

The Greek Atomic Energy Agency (GAEC) is the regulatory, advisory and competent authority on radiation protection matters with responsibility for implementing Radiation Protection Regulations. This includes recording, monitoring and introducing protective measures at workplaces with elevated natural radiation.

\section{Radon}

Greece has in place a national standard/reference level for workplaces with elevated radon levels. Greek regulation for Radiation Protection (No. 216B, 5/3/2001) paragraph 1.2.5.7 refers to action levels for radon concentrations and what is expected of an employer in cases of elevated radon levels. The enforced level for each type of workplace is $400 \mathrm{~Bq} \mathrm{~m}^{-3}$.

Radon surveys of the workplace are being carried out but as yet no activity has been identified which gives rise to elevated radon levels. If any are found workplace and/or individual monitoring will be carried out. Dose records shall be maintained if required. Work activities where radon concentration is above action levels have to be identified and authorised by the GAEC. The GAEC use a track-etch detector-counting system and Aristotle University of Thessaloonnika (AUT) use electrets.

\section{Other sources of natural radiation}

Greece has in place a national standard/reference level for workplaces with elevated sources of natural radiation. The enforced level is set at $1 \mathrm{mSv} \mathrm{y}^{-1}$ for each type of workplace. Under Greek Radiation Protection Regulation, No. 21B, 5/3/1002 paragraphs 1.2.5.3 to 1.2.5.6, 'work activities' with elevated levels of natural radiation must be identified. Individual and workplace monitoring are undertaken if required. Individual dose records are maintained with the minimum dose record level set at $1 \mathrm{mSv} \mathrm{y}^{-1}$. Various techniques are used to measure natural radiation including in situ gamma spectrometry and laboratory measurements of workplace air samples.

\section{Hungary}

\section{Radon}

Hungary has in place a national standard/reference level for workplaces with elevated levels of radon. The reference level is set at $1000 \mathrm{~Bq} \mathrm{~m}^{-3}$ in Decree No. 16/2000 (VI. 8.) EüM issued by the Ministry of Health on the implementation of Certain Provisions of the Act CXVI of 1996 on Atomic Energy.

In workplaces where it is likely that the levels of radon may lead to exposure of an employee, the employer must determine the radon concentration. If necessary the Office of the Chief Medical Officer of State of the National Public Health and Medical Officers Service may order regular individual monitoring. A preliminary survey of workplaces is in progress.

Track-etch detectors, Radamon and CR-39, and Radosys evaluating system are the measurement techniques used.

\section{Other sources of natural radiation}

In Hungary a national standard/reference level is in place to deal with elevated levels of other natural sources of radiation. An enforced dose limit of $20 \mathrm{mSv} \mathrm{y}^{-1}$ exists for mines, underground workplaces, industry and waterworks. Individual monitoring and individual dose records are carried out and maintained in accordance with the legislation. The minimum dose record level is set at $2 \mathrm{mSv} \mathrm{y}^{-1}$. A preliminary survey of workplaces is currently underway.

The radiation protection service, Frederic JoliotCurie National Research Institute for Radiobiology and Radiohygiene, provides measurement for external gamma radiation. For any other type of 


\section{A. LOPEZ ET AL}

radiation, including internal or radon exposure, an accredited laboratory must be used.

\section{Ireland \\ Radon}

Ireland has in place reference levels for workplaces with elevated levels of radon. The enforced level for each workplace is $400 \mathrm{~Bq} \mathrm{~m}^{-3}$ with an advisory level of $200 \mathrm{~Bq} \mathrm{~m}^{-3}$ being implemented for schools. Individual monitoring generally only takes place for employees in mines and underground workplaces. Workplace/area monitoring shall take place where radon levels cannot be reduced by mitigation. Individual dose records are maintained if exposure is liable to exceed $1600 \mathrm{kBq} \mathrm{h} \mathrm{m}{ }^{-3} \mathrm{y}^{-1}$ in mines or underground workplaces. A minimum dose record level is not defined. Radon in workplaces is normally measured using diffusion CR-39 track-etch detectors.

\section{Other sources of natural radiation}

Ireland has in place a reference level for workplaces with elevated levels of other sources of natural radiation. The enforced level for each workplace is $1 \mathrm{mSv}$. Individual monitoring takes place if an employee is liable to exceed $1 \mathrm{mSv} \mathrm{y}^{-1}$. The Irish Regulations do not distinguish between workplace types. Exposure of aircrew to increased levels of cosmic radiation is dealt with separately.

\section{Italy}

Radon

Italy has in place a national standard/reference level for the protection of employees from exposure to radon in the workplace. An enforced level of $500 \mathrm{~Bq} \mathrm{~m}{ }^{-3}$ is in place for underground workplaces, industry and offices, schools and day-care homes. The level for offices, schools and day-care homes is only implemented in radon prone areas.

Where an average of $500 \mathrm{~Bq} \mathrm{~m}^{-3}$ individual dose assessment is carried out to determine whether the dose is greater than $3 \mathrm{mSv} \mathrm{y}^{-1}$, therefore avoiding unnecessary remedial action.

No regular radon personal dosimetry is required. Measurements are undertaken using passive SSNTDs. The service at the National Institute of Occupational Safety and Prevention (ISPESL) is recognised by the National Agency for Environmental Protection (ANPA) and ISPESL.

\section{Other sources of natural radiation}

National standards/reference levels also exist for workplaces with elevated levels of other sources of natural radiation. A reference level of $1 \mathrm{mSv} \mathrm{y}^{-1}$ is in place for mines, industries and waterworks.
Individual and workplace monitoring is only required if remedial action has proved ineffective in reducing the exposure to less than $1 \mathrm{mSv} \mathrm{y}^{-1}$.

Measurements must be carried out by an approved dosimetry service.

\section{Latvia}

\section{Radon}

Regulations of the cabinet of ministers \#149 on protection against ionising radiation, 9 April 2002, have put in place reference levels for the protection of employees from exposure to radon. These take the form of a series of action levels as follows:

- Reference level for underground workplaces (excluding mines): action level $>400 \mathrm{~Bq} \mathrm{~m}^{-3} \mathrm{y}^{-1}$, investigation levels $>400 \mathrm{~Bq} \mathrm{~m}^{-3} \mathrm{y}^{-1}$, intervention levels $>400 \mathrm{~Bq} \mathrm{~m}^{-3} \mathrm{y}^{-1}$, exemption levels $<400 \mathrm{~Bq} \mathrm{~m}{ }^{-3} \mathrm{y}^{-1}$.

- Reference level for industry workplaces/waterworks: action level $>100 \mathrm{~Bq} \mathrm{~L}{ }^{-1}$, investigation levels $100-1000 \quad \mathrm{~Bq} \mathrm{~L} \mathrm{~L}^{-1}$, intervention levels $>1000 \mathrm{~Bq} \mathrm{~L}^{-1}$, exemption levels $<100 \mathrm{~Bq} \mathrm{~L}^{-1}$.

- Reference levels for offices, schools, day-care homes: action level $>200 \mathrm{~Bq} \mathrm{~m}^{-3} \mathrm{y}^{-1}$, intervention levels $>200 \mathrm{~Bq} \mathrm{~m}^{-3} \mathrm{y}^{-1}$, exemption levels $<200 \mathrm{~Bq} \mathrm{~m}^{-3} \mathrm{y}^{-1}$.

The Radiation Safety Centre determines workplaces with elevated levels of radon.

The equipment used to carry includes the ATMOS 12 radon gas meter, MARKUS 10 radon gas meter for soil air samples, electret ion chamber Radon Detectors (ES-, EL-) and SPER 1 monitors.

\section{Other sources of natural radiation}

Again the Regulations \#149, 9 April 2002, have put in place reference levels for the protection of employees from other sources of natural radiation. These apply to underground workplaces and again there are exemption levels, $<1 \mathrm{mSv}^{-1}$, investigation levels, $<6 \mathrm{mSv} \mathrm{y}^{-1}$, and action levels, $>1 \mathrm{mSv} \mathrm{y}^{-1}$, in place. The employer is responsible for making measurements of exposure to natural radiation in the workplace.

\section{Lithuania}

\section{Radon}

Lithuania has in place national standards/reference levels for workplaces with elevated levels of radon. For mines and other underground workplaces the reference level is $1000 \mathrm{~Bq} \mathrm{~m}^{-3}$ while for industry, waterworks, offices, schools and day-care homes it is $400 \mathrm{~Bq} \mathrm{~m}$ m$^{-3}$. No individual or workplace 
monitoring takes place. The indoor radon situation has to be determined in all workplaces that are in radon prone areas. Identification of such areas has begun recently. E-PERM electrets manufactured by RadElecInc. USA, are used to measure indoor radon.

\section{Other sources of natural radiation}

Lithuania has in place national standards/reference levels for workplaces with elevated levels of other sources of natural radiation. The dose limit for most workplaces is $50 \mathrm{mSv} \mathrm{y}^{-1}$ in classified working areas. However, the dose limit for offices, schools and day-care centres is set at $5 \mathrm{mSv} \mathrm{y}^{-1}$.

Thermoluminescence dosemeters (TLDs) manufactured by RADOS, Finland, are used for monitoring external exposure. Internal dosimetry, where required, is performed using bioassay. Measurements are carried out by the Radiation Protection Centre in Vilinius.

\section{The Netherlands}

In the Netherlands no national standards/reference levels exist for radon in workplaces. Occasionally, workplace/area monitoring takes place.

Reference levels are in place for the protection of employees from other sources of natural radiation. This is set at $1 \mathrm{mSv} \mathrm{y}^{-1}$ for all workplaces. The minimum dose record level is $0.01 \mathrm{mSv}$. All the above figures relate to external exposure only.

\section{Norway}

\section{Radon}

In Norway the advisory reference level for mines and underground workplaces is $1000 \mathrm{~Bq} \mathrm{~m}^{-3}$ and for industry, waterworks, offices, schools and day-care centres it is $200 \mathrm{~Bq} \mathrm{~m}^{-3}$. Theses advisory standards will be replaced by 'enforced' regulations in 2003.

Employers are advised to measure radon levels, and an individual dose register will be established if or when radon levels above $2000 \mathrm{~Bq} \mathrm{~m}^{-3}$ are found. The minimum dose record level is $6 \mathrm{mSv} \mathrm{y}^{-1}$. Radon measurements are carried out by a number of companies. There is no formal approval system, but the Norwegian radiation protection authority has a list of 'recommended companies', based on measurement methods and participation in international intercomparisons.

\section{Other sources of natural radiation}

Technically enhanced natural radiation is subjected to the general dose limit of $20 \mathrm{mSv} \mathrm{y}^{-1}$. Future legislation will apply the following classification standard for technically enhanced natural radiation:

- $<1 \mathrm{mSv} \mathrm{y}^{-1}$ no action required

- $1-6 \mathrm{mSv} \mathrm{y}^{-1}$ workplace/area monitoring shall be performed

- $>6 \mathrm{mSv}^{-1}$ individual dose assessments shall be performed.

The Radiation Protection Authorities in Denmark, Finland, Iceland, Norway and Sweden have issued recommendation for Naturally Occurring Radioactivity in the Nordic Countries. Information is to be found at http://www.ssi.se/english/Flaggboken. pdf.Additional information can be found at http:// www.nrpa.no/fpinternet/english/.

\section{Poland}

\section{Radon}

In Poland the current standards and reference levels relating to radon exposure derive from Polish Mining Law. A reference level of $2 \mu \mathrm{J} \mathrm{m}^{-3}$ is in place for employees working in mines. This value also applies to other underground activities, e.g. tunnel drilling, undertaken under the Polish Geographical and Mining Law.

Individual and workplace monitoring is undertaken in mines. Individual records are maintained with the minimum dose record being set at $6 \mathrm{mSv} \mathrm{y}^{-1}$.

The measurements are carried out using dust samplers, Barbara-3A and Alpha-31 probe, and thermoluminescent detectors. For individual monitoring the Alpha-2000 probe with aspirator ALFA-DUST can be used.

Mines carrying out radon evaluations are overseen by the Polish Mining Authority. Other measurements must be carried out by an accredited laboratory. The Polish Centre For Accreditation is the accreditation body.

\section{Other sources of natural radiation}

Polish 'Atomic Law', introduced in July 2002 put in place regulations for workplaces with elevated levels of natural radiation. An intervention level of $5 \mathrm{mSv} \mathrm{y}^{-1}$ is laid down for those working in mines and underground workplaces that come under Polish Geographical and Mining Law.

Individual monitoring and workplace monitoring take place in mines. The minimum record level is $6 \mathrm{mSv} \mathrm{y}^{-1}$.

Measurement techniques for mines usually involve a dose-rate meter, Gamma 31, and a TLD. Concentrations of ${ }^{226} \mathrm{Ra}$ and ${ }^{228} \mathrm{Ra}$ are determined in mining waters and sediments as per the mining regulations.

Measurements must be carried out by a laboratory accredited by the Polish Centre for Accreditation. Measurements in mines are overseen by the Polish Mining Authority. 


\section{Portugal}

The EU Directive 96/29/EURATOM is not yet transposed into National legislation. Uranium miners are treated as radiation workers. They are monitored for external exposure to photons using TLD. Individual dose records are maintained. This activity is coming to an end with all uranium mines being closed down.

\section{Serbia and Montenegro}

\section{Radon}

A national standards/reference levels are in place in Serbia and Montenegro to deal with radon in workplaces. A reference level of $1000 \mathrm{~Bq} \mathrm{~m}^{-3}$ is in place for mines, underground workplaces, industry and waterworks and $400 \mathrm{~Bq} \mathrm{~m}^{-3}$ is in place for offices, schools and day-care homes. No individual or workplace/area monitoring takes places.

$\mathrm{Cr}-39$ is generally used to carry out radon measurements. A number of facilities undertake radon measurements including the Institute of Nuclear Sciences, Vinca, the Security Institute, the Institute of Occupational Health, Belgrade and the Institute of Physics, Novi Sad.

\section{Slovak Republic}

\section{Radon}

Slovak Republic has in place national standards/ reference levels for the protection of employees from radon in the workplace. The reference level is set at $1000 \mathrm{~Bq} \mathrm{~m}^{-3}$ for mines, underground workplaces, industry and waterworks and $500 \mathrm{~Bq} \mathrm{~m}^{-3}$ for offices, schools and day-care homes.

Individual monitoring takes place for those employed in mines and other underground workplaces. Workplace/area monitoring takes place in underground workplaces, including mines, and offices, schools and day-care homes. Individual dose records are maintained with a minimum dose record level being set at $4 \mathrm{kBq} \mathrm{h} \mathrm{m}{ }^{-3}$.

Passive SSNTD-type CR-39 is used for measurement of personal radon doses. The calibration of detectors is carried out in the reference radon and radon progeny measuring chamber, at the State Meteorological Centre of Institute of Preventive and Clinical Medicine, Bratislava.

\section{Slovenia}

Radon

National standards/reference levels shall be put in place in Slovenia in the future. At present an advisory level of $1000 \mathrm{~Bq} \mathrm{~m}^{-3}$ for underground workplaces, industry, waterworks and $600-1000 \mathrm{~Bq} \mathrm{~m}^{-3}$ for offices, schools and day-care homes. Individual and workplace monitoring takes place. Individual dose records are maintained with a minimum dose record level of $0.01 \mathrm{mSv} \mathrm{y}^{-1}$ being applied. Nuclear track detectors and continuous monitors are used to measure radon.

\section{Other sources of natural radiation}

Slovenia has in place national standards/reference levels for the protection of employees from other sources of natural radiation in the workplace. A reference level of $1 \mathrm{mSv} \mathrm{y}^{-1}$ exists for employees in industry, waterworks, offices, schools and day-care homes. Individual and workplace monitoring takes place. Individual dose records are maintained with a minimum dose record level of $0.01 \mathrm{mSv} \mathrm{y}^{-1}$ being applied. Measurement techniques include TLD, dose-rate meters and gamma spectrometry.

The Health Inspectorate is responsible for all reference levels regarding natural sources of radiation that are not already included in regulations. For all employees not working with radiation a reference level of $1 \mathrm{mSv} \mathrm{y}^{-1}$ applies.

\section{Spain}

Title VII of the EURATOM 96/29 Directive was implemented in Spain in 2001 through the 'Real Decreto 783/2001 de 6 de julio, por el que se aprueba el Reglamento sobre protección sanitaria contra radiaciones ionizantes'. The Nuclear Safety Council $(\mathrm{CSN})$ is the Spanish regulatory body in charge of the approval of Individual Monitoring Services (IMS) for the control of exposed workers.

There is no national regulation or enforced reference levels in Spain relating to the protection of employees from exposure to radon or natural sources of radiation in the workplace. The Nuclear Safety Council (CSN), is involved in different projects and supervises tasks related to the evaluation of risks in cases of radon and natural sources exposures. A Spanish Natural Radiation Map has been developed, and CSN has collaborated with the Ministry of Development for generating protocols for soil gas radon measurements and performing a guide for new building radon safe construction. In collaboration with INTE (Technical University of Catalonia, UPC) is achieved the setting up of a radon reference chamber in Spain in order to provide reference atmosphere for the calibration of radon detectors; a preliminary guide for the accreditation of radon measurement laboratories is being developed.

\section{Sweden}

\section{Radon}

Sweden has in place national standards/reference levels for workplaces with elevated levels of radon. 
For mines a reference level of $2.5 \mathrm{MBq} \mathrm{h} \mathrm{m}{ }^{-3} \mathrm{y}^{-1}$ applies. For other underground workplaces, industry, waterworks, offices, schools and day-care homes it is $400 \mathrm{~Bq} \mathrm{~m}{ }^{-3}$. The reference level for offices, schools and day-care homes will be reduced to $200 \mathrm{~Bq} \mathrm{~m}^{-3}$ as a new environmental quality objective has been adopted by the Swedish Parliament.

Some categories of workers are monitored but dose records for employees monitored in workplaces with elevated levels of radon are not maintained. Workplace/area monitoring takes place in mines.

CR-39 alpha-track detectors with an NRPB holder are used to measure radon. The detector is described in Radiation Protection Dosimetry, $45(1-4)$, 65-71 (1992). The Work Environment Authority makes requests for workplace measurements to be undertaken.

The Radiation Protection Authorities in Denmark, Finland, Iceland, Norway and Sweden have issued recommendation for Naturally Occurring Radioactivity in the Nordic Countries. Information is to be found at http://www.ssi.se/english/Flaggboken.pdf.

\section{Switzerland}

\section{Radon}

Switzerland has in place national standards/reference levels for workplaces with elevated levels of radon. The reference levels are set at $3000 \mathrm{~Bq} \mathrm{~m}^{-3}$ for underground workplaces, industry and waterworks and $1000 \mathrm{~Bq} \mathrm{~m}{ }^{-3}$ for offices, schools and day-care homes. Individual monitoring is not undertaken. Workplace/are monitoring is undertaken and the competent body for these measurements is the National Accident Insurance Fund (Suva).

\section{Ukraine}

\section{Radon}

Ukraine has in place national standards/reference levels for workplaces with elevated levels of radon. The reference levels are set at $750 \mathrm{~Bq} \mathrm{~m}^{-3}$ for underground workplaces, industry and waterworks and 250 (150 for new dwellings) $\mathrm{Bq} \mathrm{m}^{-3}$ for offices, schools and day-care homes. Individual monitoring takes place for workers in offices, schools and day-care homes. The minimum dose record level is set at $0.8 \mathrm{mSv}$.

Additional information can be found at http:// webua.net/nuc/Index.htm.

\section{CONCLUSIONS}

Both the International Commission on Radiological Protection and the Council of the European Union recommend that countries take action to deal with radon and other sources of natural radiation in the workplace. The information gathered in this survey gives a useful indication of the state of implementation of Title VII of the BSS Directive, which relat to exposure to natural radiation sources across Europe. However, it should noted that the findings are incomplete as not all invited countries replied to the questionnaire.

The majority of countries have national standards or reference levels in place, while some have yet to complete the process. Most countries have standards or reference levels for mines or other underground works, which reflect exposure levels expected by workers. For workplaces, such as offices and schools these tend to be set at levels that apply to the members of the public. Approaches to development and implementation of such standards and reference levels appear to be country specific, therefore leading to a lack of harmonisation in this area.

The survey indicates that radon in the workplace presents a particular concern. The fact that there is such a wide variety of standards and reference levels employed by the participating countries complicates the issue. Radon exposure results in an internal dose that often dominates the dose received from natural sources. The integration of internal and external doses for exposure to radon and other sources of natural radiation is therefore difficult. This is due in part to the use of different units of measurement but also to the uncertainty involved in converting radon exposure to dose.

Of particular interest is the reported range in the recording of a 'minimum dose record' by participating countries, a factor of more than 100 . This could be due to each respondent's interpretation of the concept 'minimum dose record'

In conclusion, this investigation clearly indicates that the pursuit of increased harmonisation among European countries, not least in the areas of regulation and reference levels in the workplace, is required. This would provide a more solid basis on which to investigate the integration of monitoring for internal and external exposures and from workplace monitoring to give a complete and consistent system of individual monitoring

\section{ACKNOWLEDGEMENTS}

The authors are grateful to the following services that responded to their questionnaire. The services are given in alphabetic order of country code and name of service.

1. BE, SCK-CEN, H. Vanmarcke, Boeretang 200, Mol, 2400 Belgium, Tel. +32 14332829, Fax +32 14321056, E-Mail: hvanmarc@sckcen.be.

2. BG, Laboratory of Dosimetry and Radiation Protection, St. Kliment Ohridski University of 
Sofia, Pressyanov, D. S., Faculty of Physics, 5 James Bourchier Blvd.Sofia, BG-1164, Bulgaria, Tel. +359 26256 268, Fax +359 29625 276, E-Mail: pressyan@hotmail.com.

3. CH, Swiss National Accident Insurance Fund (Suva), Hammans Michel, Fluhmattstrasse 1, Luzern, CH-6002, Luzern, Switzerland, Tel. +41 41 4195111, Fax +41 41 4196213, E-Mail: michel.hammans@suva.ch.

4. CZ, National Radiation Protection Institute, Jiri Hulka, Srobarova 48, Praha 10, CZ-100 00, Czech Republic, Tel. +420 26708 2640, Fax + 42026731 1410, E-Mail: jhulka@suro.cz.

5. DE, Bundesamt für Strahlenschutz (German Federal Office for Radiation Protection), Thomas Beck, Köpenicker Allee 120 - 130, Berlin, D-10318, Germany, Tel. +49 1888333 4211, Fax +491888333 4215, E-Mail: tbeck@bfs.de.

6. DK, National Institute of Radiation Hygiene, Mette Oehlenschlaeger, Knapholm 7, DK 2880 Bagsværd, Denmark, Tel. +45 445434 54, Fax +45 445434 50, E-Mail: moe@sis.dk.

7. EE, Estonian Radiation Protection Centre (ERPC), Toomas Kööp, Kopli str. 76, Tallinn, EE-10416, Estonia, Tel. +372 660 3336, Fax+372660 3352, E-Mail: Toomas.koop@ekk. envir.ee.

8. ES, CIEMAT-Internal Dosimetry; Avda. Complutense 22, 28040 Madrid, Spain.

9. FI, STUK-Radiation and Nuclear Safety Authority, Mika Markkanen, PO Box 14, Helsinki, FIN-00881, Finland, Tel. +3589 759881, Fax +358 9 75988500, E-Mail: mika. markkanen@stuk.fi.

10. GR, Greek Atomic Energy Commission, Department of Environmental Radioactivity, Virginia Koukouliou, PO Box 60092, Agia Paraskevi, 15310, Attiki, Greece. Tel. +30 10 6506700, Fax + 30103506748, E-Mail: vkoukoul (a)eeae.nrcps.ariadne-t.gr.

11. HU, 1st Dept. of Radiation Hygiene, OKK, Fréderic Joliot-Curie National Research Institute for Radiobiology and Radiohygiene, A. Kerekes, Anna 5, PO Box 101, Budapest, H-1775, Hungary, Tel. +36 1482 2015, Fax +36 1229 1931, E-Mail: kerekes@hp.osski.hu.

12. IR, Radiological Protection Institute of Ireland, Natural Radiation Department, D. Pollard, 3 Clonskeagh Square, Clonskeagh Road, IR14, Dublin, Ireland, Tel. +353 12697766 , Fax +353 1 2697437, E-Mail: dfenton@rpii.ie.

13. IT, Laboratorio Radiazioni Ionizzanti e Non Ionizzanti - ISPESL, Rosabianca Trevisi, Via Fontana Candida, 1, Monteporzio Catone, 40, (RM) Italy, Tel. +396941 814 34, Fax Tel +39 6 941814 19, E-Mail: trevisi@dil.ispesl.it.

14. LT, Radiation Protection Centre, Morkunas G., Kalvariju 153, LT-2042, Lithuania, Tel.
+370 2 754693, Fax +370 2 754692, E-Mail: genmo@takas.lt.

15. LV, Radiation Safety Centre, Konstantins Bogucarskis, 165 Maskavas, Riga, LV-1019, Latvia, E-Mail: K.Bogucarskis@rdc.gov.lv.

16. NL, NRG Radiation \& Environment, van Dijk, W., Utrechtseweg 310, PO Box 9034, ARNHEM, 6800 ES, Netherlands, Tel. +31 2635624 69, Fax +31 2644507 87, E-Mail: w.vandijk@nrg-nl.com.

17. NO, Norwegian radiation protection authority, Tor Wøhni, Grini Næringspark 13, PO Box 55, N-1332 Østerås, Norway, Tel. +476716 25 00, Fax +47 671474 07, E-Mail: nrpa@nrpa.no.

18. PL, Central Mining Institute, SKOWRONEK J., Plac Gwarkow 1, Katowice, 40-166, Poland, Tel. +48-32-2592382, Fax +48-32-2596533, E-Mail: j.skowronek@gig.katowice.pl.

19. PT, ITN-DPRSN, Estrada Nacional 10. Apartado 21, Lisboa, 2686-953 Sacavém, Portugal, +351 2199460 00, Fax +351 2199419 95, E-Mail: Dprsn@itn.pt.

20. SE, Swedish Radiation Protection Authority, Lars Mjönäs, Solna Strandväg 96, SE-17116 Stockholm, Sweden, Tel. +46 872971 00, Fax +468729 7108, E-Mail: Lars.mjones@ssi.se.

21. SL, Institute of Occupational Safety, Peter Jovanovič PJ, Bohoriceva 22 a, Ljubljana, 1000 Slovenia, Tel. +386 14320 254, Fax + 386 386123 562, E-Mail: Peter.jovanovic@zvd.si.

22. UA, Laboratory for Hygiene of Natural Radiation Sources. Research Centre for Radiation Medicine AMS Ukraine, Tatyana A. Pavlenko, Melnikova 53, 4050, Kiev, Ukraine, Tel. ++380 4424458 74, E-Mail: pta@rpi.kiev.ua.

23. YU, Institute of Nuclear Sciences Vinca, Zora S. Zunic, PO Box 522, Belgrade, 11000, Serbia and Montenegro, Tel.+381 11 4440871, Fax +381 11 3440100, E-Mail: zzunic@verat.net.

\section{REFERENCES}

1. International Commission on Radiological Protection. 1990 Recommendations of the International Commission on Radiological Protection. ICRP Publication 60. Ann. ICRP 21(1-3) (Oxford: Pergamon Press) (1990).

2. European Commission. Council Directive 96/29 EURATOM of 13 May 1996 laying down basic safety standards for the protection of the health of workers and the general public against dangers arising from ionizing radiation. Off. J. No L 159, 1-114 (1996).

3. International Atomic Energy Agency. Radiation protection against radon in workplaces other than mines. Safety Reports Series No. 33: ISSN 1020-6450, STI/ PUB/1168 ISBN 92-0-113903-9, (Vienna: IAEA) (2003).

4. Committee on the Biological Effects of Ionizing Radiation (BEIR-VI). Health Effects of Exposure to Radon, US National Research Council Report (Washington, DC: National Academy Press) (1998). 
5. International Atomic Energy Agency. International basic safety standards for protection against ionising radiation and for the safety of radiation sources, (Vienna: IAEA) (1996).

6. European Commission. Recommendations for the implementation of title VII of the European Basic Safety Standards Directive (BSS) concerning significant increase in exposure due to natural radiation sources. Radiation Protection Series 88 (Office for Official Publications of the European Commission) (1997).

7. European Commission. Reference levels for workplaces processing materials with enhanced levels of naturally occurring radio nuclides. Radiation Protection Series 95 (Luxembourg Office for Official Publications of the European Commission) (1999).

8. International Commission on Radiological Protection. Protection against Radon-222 at home and at work. ICRP Publication 65. Ann. ICRP 23(2) (Oxford: Pergamon Press) (1993).

9. European Commission. Effluent and dose control from European Union NORM industries: Assessment of current situation and proposal for a harmonised Community approach. Radiation Protection Series 135 (Luxembourg Office for Official Publications of the European Commission) (2003).

10. International Commission on Radiological Protection. Limits for inhalation of Radon Daughters by Workers. ICRP Publication 32. Ann. ICRP 6(1) (Oxford: Pergamon Press) (1981).

11. Marsh J. W. and Birchall A. Sensitivity analysis of the weighted equivalent lung dose per unit exposure from radon progeny. Radiat. Prot. Dosim. 87, 167-178 (2000).

12. Kendall, G. M. and Smith, T. J. Doses to organs and tissues from radon and its decay products. J. Radiol. Prot. 22, 389-406 (2002).

13. International Commission on Radiological Protection. Human respiratory tract model for radiological protection. ICRP Publication 66. Ann. ICRP 24(1-3) (Oxford: Pergamon Press) (1994).

14. United Nations Scientific Committee on the Effects of Atomic Radiation. Sources and effects of ionising radiation. UNSCEAR 2000 Report to the General Assembly, with scientific annexes (New York: United Nations) (2000).

15. Birchall, A. and James A. C. Uncertainty analysis of the effective dose per unit exposure from radon progeny and implications for ICRP risk-weighting factors. Radiat. Prot. Dosim. 53, 133-140 (1994).

16. Nero AV., Radon and its Decay Products in Indcor Air: Measurement Techniques. In: Radon and its Decay Products in Indcor Air (Nazaroff W.M., and Nero AV., Eds) Wiley, New York, pp 32-33 (1988).

17. Kottrappa, P., Dempshey, J. C., Stieff, L. R. and Ramsey, R. W., A practical electret passive environmental radon monitor system for indoor ${ }^{222} \mathrm{Rn}$ measurement. Health Phys. 58, 461-467 (1990).

18. OECD Nuclear Energy Agency. Group of experts report on metrology and monitoring of radon, thoron and their daughter products. (Paris: OECD) (1985).

19. George, A. C. State-of-the-art instruments for measuring radon/thoron and their progeny in dwellings: a review. Health Phys. 70, 451-463 (1996). 